\title{
Effects of heavy rainfall on the slope stability - A case study on Imogiri Cemetery: The graveyard complex of Mataram Royal Kings
}

\author{
Shofwatul Fadilah* and Djoko Luknanto \\ Department of Civil and Environtmental Engineering, Faculty of Engineering, Universitas Gadjah Mada, Indonesia
}

\begin{abstract}
Rainfall is the most common cause of landslides in Indonesia. On March 17, 2019, a landslide occurred in the Imogiri Cemetery, Mataram Royal Kings Graveyard Complex. It was expected to have been triggered by heavy rainfall of $148 \mathrm{~mm} \mathrm{~d}^{-1}$ intensity. This research aims to determine the effect of rainfall on the slope stability on the landslide at the Imogiri Cemetery. The study was carried out by slope stability modelling using Geostudio software. Rainfall information and soil characteristics data obtained from testing soil samples in the Soil Mechanics Laboratory, Civil and Environmental Engineering, Universitas Gadjah Mada, were used as input on the software. The output of the analysis is the factor of safety (FS) value, defined as the ratio of the shear strength to the shear stress. Without the rains, the FS value is about 2.44 , which means the slope stability is stable. After heavy rainfall, the FS value decreased to 1.209 at the end of the simulation, which indicates happen the slope instability. Based on the simulation, the FS value depends on the volume of water content and hydraulic conductivity of the soil. Result of this study shows that heavy rainfall can trigger slope instability in the Imogiri Cemetery.
\end{abstract}

\section{Introduction}

Landslides occur due to disturbance of slope stability [1]. Landslides occurred on slopes with shear resistance of the ground or rock smaller than the weight of the soil mass or the rock itself, so a shear strength will be decrease and shear stress will be increase [2]. Landslides can be trigger by the heavy rainfall [3-4], steep slopes, less dense and thick soil, erosion, reduced vegetation cover, and an earthquake $[6,7]$. In Indonesia, rainfall is the most common cause of landslides.

Rainwater infiltrations cause an increase of pore water pressure in the soil [8]. It can make the slope load increases and will trigger the landslides [9]. Not all types of rainfall can trigger the landslides. Only heavy rainfall with an intensity higher than $70 \mathrm{~mm} \mathrm{~d}^{-1}$ or $100 \mathrm{~mm} \mathrm{~d}^{-1}$ can trigger the landslides [10]. Heavy rainfall will only be effective in triggering landslides if the soil is easy absorbing water with a steep slope $[11,12]$. On March 17, 2019, a landslide occurred in the Imogiri Cemetery, Mataram Royal Kings Graveyard Complex, Imogiri, Yogyakarta. The landslide was expected to have been triggered by heavy rainfall of $148 \mathrm{~mm} \mathrm{~d}^{-1}$ intensity [13, 14]. At other hands, some news state that landslides happened on Imogiri Cemetry not only triggered by heavy rainfall but also triggered by small earthquakes happened frequently [13].
Two houses buried and three deaths during the landslides [14]. In this study, slope stability will be analyzed only from the effect of heavy rains without concern to other triggers.

\section{Slope stability}

The concept of slope stability refers to the limit equilibrium. The condition of the slope stability is determined by the value of the factor of safety $(F S)$. It is defined as the ratio of the shear strength to the shear stress [15]. The factor of safety value depends on cohesion $(c)$ value and the angle of internal friction $(\phi)$. The higher the soil cohesion value, the higher the number of safety factors. In general, dry soils have higher soil cohesion $(c)$ values. Referring to Equation. 2.1 the factor of safety $F$, for strength, may be expressed as follows:

$$
F=\frac{\tau}{\tau_{d}}
$$

where $\tau$ is shear strength exerted on the soil and $\tau_{d}$ is shear stress applied to the soil. Based on the factor of safety, the slope stability divided into some classes shown in Table 1.

\footnotetext{
* Corresponding author: shofwatul.fadilah@mail.ugm.ac.id
} 
Table1. Slope stability classification [16]

\begin{tabular}{|c|c|}
\hline Factor of Safety $(\boldsymbol{F S})$ & Classification \\
\hline$F>1.5$ & Stable \\
\hline $1.25<F<1.5$ & Medium stable \\
\hline $1<F<1.25$ & Less stable \\
\hline$F<1$ & Unstable \\
\hline
\end{tabular}

Slope stability analysis methods differ between homogeneous and inhomogeneous soils. For homogeneous soils with an uncertain flow of seepage in the soil, the suitable analysis method is the Method of Slice. The most popular and widely used of the Method of Slice is the Fellenius Method. The ordinary method of slices was found in 1927 by Fellenius, considers the forces acting on the right and left sides of any slice to have a zero resultant in the direction perpendicular to the landslide [16].

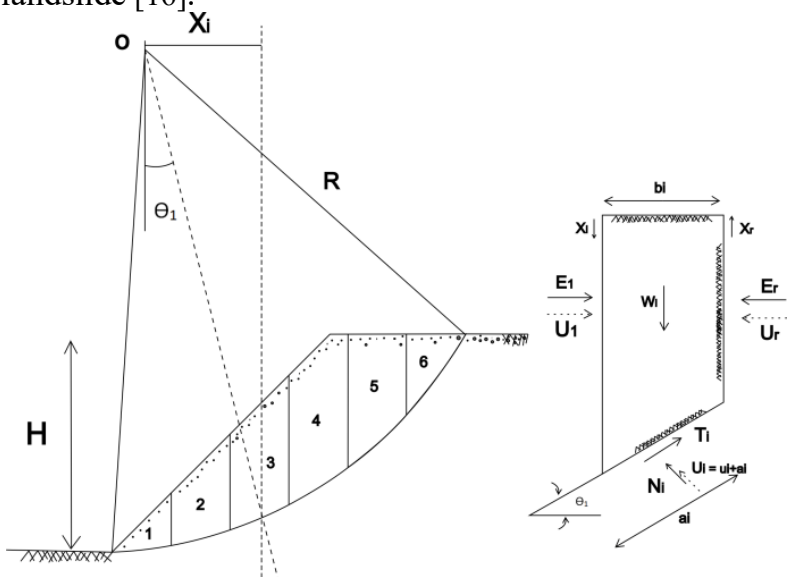

Fig. 1. Stresses and forces acting on the slice [16]

With this assumption, the balance of the vertical direction and the forces that work by taking into account the pore water pressure as follows:

$$
N_{i}+U_{i}=W_{i} \cos \Phi_{i}
$$

or

$$
\begin{aligned}
N i & =W_{i} \cos \Phi_{i}-U i \\
& =W_{i} \cos \Phi_{i}-u_{i} . a_{i}
\end{aligned}
$$

Slope stability define as:

$$
F=\frac{\sum M_{r}}{\sum M_{d}}
$$

where,

$$
\sum M_{r}=R \sum_{i=1}^{i=n}\left(W_{i}+\sin \theta_{i}\right)
$$

and,

$$
\sum M_{r}=R \sum_{i=1}^{i=n}\left(c a_{i}+N_{i} \operatorname{tg} \varphi\right)
$$

to obtain:

$$
F=\frac{\sum_{i=1}^{i=n}\left(c a_{i}+N_{i} \operatorname{tg} \varphi\right)}{\sum_{i=1}^{i=n} W_{i} \sin \theta_{i}}
$$

If there is water on the slope, the pore water pressure in the landslide field does not increase the moment due to the soil that will slide $\left(M_{d}\right)$, because the resultant force due to pore water pressure passes through the centre of the circle. When Equation 3 substitute to Equation 7, obtained $\mathrm{F}$ equation shown in Equation 8.

$$
F=\frac{\sum_{i=1}^{i=n} c a_{i}+\left(W_{i} \cos \theta_{i}-u_{i}\right) \operatorname{tg} \varphi}{\sum_{i=1}^{i=n} W_{i} \sin \theta_{i}}
$$

where $F$ is factor of safety, $M_{r}$ is number of shear resistant moments along the landslide field, $M_{d}$ is number of moments of soil mass of landslides, $c$ is soil cohesion $\left(\mathrm{kN} / \mathrm{m}^{2}\right), \varphi$ is angle internal friction $\left(^{\circ}\right), a_{\mathrm{i}}$ is the length of the curve of the circle on the slice $i$-th, $R$ is radius in the landslide field, $n$ is number of slices, $W_{i}$ is mass of slice soil $i$-th, and $\theta_{\mathrm{i}}$ is the angle as defined in Figure 1. If there are forces other than the load of the land itself, such as the load of the building on the top of the slope, the moment due to this load is calculated to be $M_{d}$.

\section{Data and methodology}

\subsection{Study area}

The research location is in the Imogiri Cemetery, Mataram Royal Kings Graveyard Complex, Imogiri, Yogyakarta. Based on the topography, the landslide area is dominated by gardens, hills, and residential areas. Based on the morphology, the location of the landslide has a slope ranges between $20^{\circ}$ and $40^{\circ}$. Based on lithology, the location of the landslide is composed of volcanic breccias which sustain weathering and form a thick layer of soil [17].

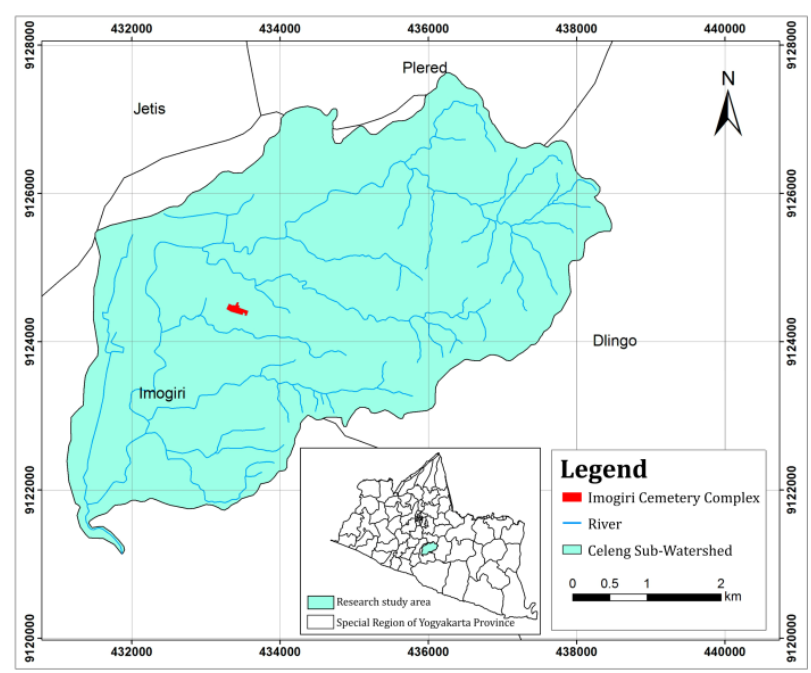

Fig. 2. Research study area

\subsection{Data}

\subsubsection{Soil data}

Soil samples data was tested in the Soil Mechanics Laboratory, Civil and Environmental Engineering, Universitas Gadjah Mada. From the soil test, obtained the soil index properties and permeability coefficient as shown in Table 2. 
Table 2. Soil index properties and permeability coefficient

\begin{tabular}{|c|c|c|c|}
\hline Parameter & Top Soil & $\begin{array}{c}\text { Second } \\
\text { layer soil }\end{array}$ & $\begin{array}{c}\text { Third layer } \\
\text { soil }\end{array}$ \\
\hline Depth $(h)(\mathrm{m})$ & $1.5-2$ & $2.5-3$ & $6-6.5$ \\
\hline $\begin{array}{c}\text { Moisture Content } \\
(w)(\%)\end{array}$ & 26.51 & 22.29 & 37.45 \\
\hline $\begin{array}{c}\text { Spesific Gravity } \\
\left(G_{s}\right)\end{array}$ & 2.61 & 2.53 & 2.5 \\
\hline Void ratio $(e)$ & 1.06 & 0.73 & 0.82 \\
\hline $\begin{array}{c}\text { Degree of } \\
\text { saturation }(\%)\end{array}$ & 65.05 & 77.42 & 100 \\
\hline$\phi\left({ }^{\circ}\right)$ & 34.51 & 36.83 & 34.01 \\
\hline $\begin{array}{c}\text { Cohesion }(c) \\
\left(\mathrm{gr} / \mathrm{cm}^{3}\right)\end{array}$ & 0.13 & 0.09 & 0.13 \\
\hline $\begin{array}{c}\text { Coefficient of } \\
\text { permeability } \\
(\mathrm{m} / \mathrm{s})\end{array}$ & $1.70 \mathrm{E}-07$ & $8.50 \mathrm{E}-09$ & $1.10 \mathrm{E}-06$ \\
\hline
\end{tabular}

\subsubsection{Loads data}

This study used two types of loads data, are:

\section{Structure loads}

Structure loads is the Imogiri cemetery buildings used $10 \mathrm{kN} \mathrm{m}^{-2}$ following applicable standards (SNI 1727-2013) [18]. The Imogiri cemetery complex load is estimated at 100 tons with a cemetery area of 1650 $\mathrm{m}^{2}$ (half of the total cemetery area). This value is smaller than the minimum construction load based on SNI, so it is appropriate.

2. Rainfall loads

Based on the Meteorological, Climatological, and Geophysical Agency of Indonesia report, rainfall during landslides at the Imogiri cemetery complex on March 17, 2019, reached $148 \mathrm{~mm} \mathrm{~d}^{-1}$. Rainfall data of $70 \mathrm{~mm} \mathrm{~d}^{-1}$ intensity or more than $100 \mathrm{~mm} \mathrm{~d}^{-1}$ intensity indicates the type of heavy rain that can trigger landslides. This rain data is then converted into an hourly rain form with the ABM method to obtain rain infiltration values. rain infiltration value will be input to the software as flux unit $(q)$ boundary conditions [19].

\subsection{Data analysis}

Analysis of the Imogiri cemetery slope stability was analyzed using the Fellenius (Ordinary). The model was simulated using SLOPE/W and SEEP/W on Geostudio Software. This method was chosen because it is simple and have errors are still in the safe category. Modelling was simulated for two conditions, that are slope stability with and without rainfall loads. Modelling with the rainfall load was simulated for $13 \mathrm{~h}$. The basic equation on SEEP/W is the non-permanent seepage defined as Equation 9 [16].

$$
\frac{d h}{d r}=\frac{k}{m_{v} \cdot \gamma_{w}}\left(\frac{d^{2} h}{d x^{2}}+\frac{d^{2} h}{d y^{2}}\right)
$$

where $h$ is high of energy, $k$ is permeability coefficient, $m_{v}$ is stability coefficient and $\gamma$ is weight of water unit.

\section{Result and discussion}

\subsection{Slope stability without rainfall loads}

The output of the analysis is the factor of safety (FS) value, defined as the ratio of the shear strength to the shear stress. The result of slope stability simulation using SLOPE/W without rainfall load was obtained a factor of safety (FS) value about 2.442 as shown in Figure 3. This simulation just influenced by the structure loads from Imogiri cemetery. The SF value shows that the structure loads do not cause landslides in the Imogiri Cemetery.

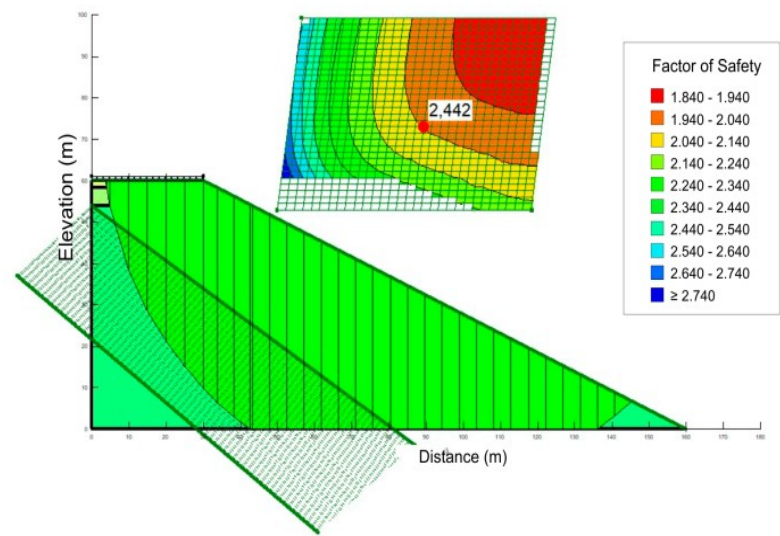

Fig. 3. The results of the simulation of slope stability without rain loads using $\mathrm{W} /$

\subsection{Slope stability with rainfall loads}

Slope stability modelling using SEEP/W in Geostudio software is used to investigate the effects of continuous rainfall on the slope stability on the landslide at the Imogiri cemetery. The analysis called as transient seepage analysis. A transient analysis can be used to evaluate the effect of altering the slope of the volumetric water content function $\left(m_{w}\right)$ [19]. It depends on the initial conditions. Initial conditions in this study used steadystate conditions, assuming that there is no flooding in the initial stage $(\mathrm{H}=0 \mathrm{~m})$ and its value not changing until the simulation end. Rainwater infiltration value is input as unit flux $(q)$ boundary conditions. Rainwater infiltration is very influential on the slope stability. Rainwater infiltration will continuously increase the degree of soil saturation, but the infiltration rate will decrease with increasing the degree of soil saturation.

The value of the soil saturation degree greatly influences the soil suction value. Soil suction is the ability of the soil to absorb water [20]. The higher the value of the soil saturation degree, the lower the soil suction value. Soil suction value influenced by porosity and volumetric water content. The higher soil porosity value, the lower soil suction value. The volumetric water content value is contrary to the soil suction value. The relationship between soil suction values and volumetric water content, expressed as a soil-water curve characteristic (SWCC) as shown in Figure 4., shows that 
the volumetric water content value is contrary to the value of soil matric suction. At the beginning of the simulation, when the soil is an unsaturated condition, every part of the soil layer has the different value of the volumetric water content. The highest value of volumetric water content in an unsaturated condition is topsoil. In the end of the simulation, when the soil is a saturated condition, all of the soil parts have the same value of volumetric water content. From Figure 4 can conclude that rainfall infiltration causes the volumetric water content increase, which leads to the matric suction of soil to decrease[21].

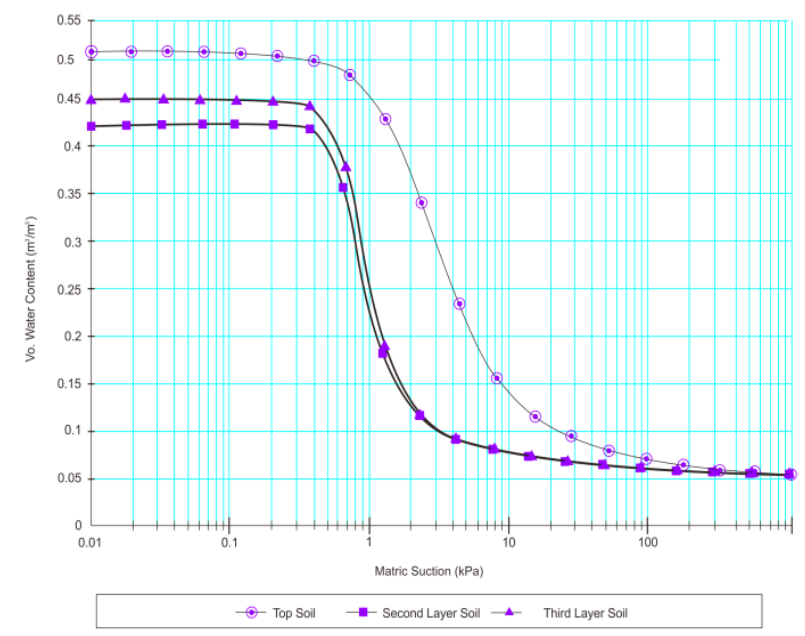

Fig. 4. Soil-water caracteristic curve

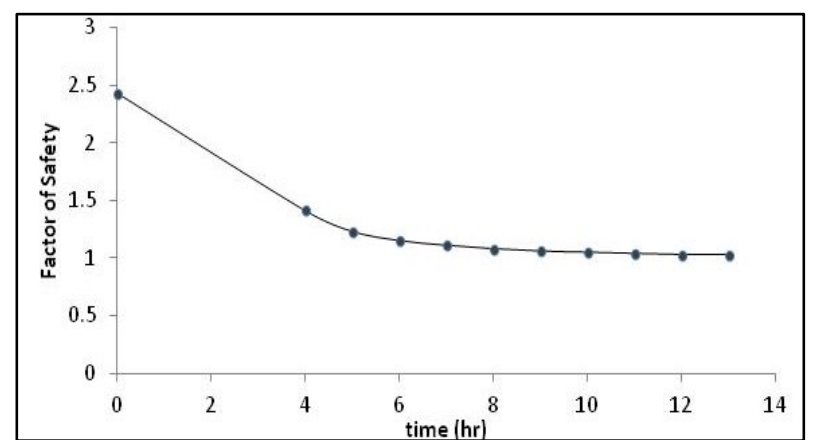

Fig. 5. The changes of the factor of safety to rainfall duration

Figure 5 shows that after heavy rains crashed the slope, the factor of safety (FS) value decreased continuously. In the initial stage of transient seepage analysis, the safety factor value is about 2.43 . This value is smaller than the factor of safety (FS) in the slope stability simulation without rainfall loads. It happens because the soil condition in the transient seepage analysis is saturated. At the end of the transient seepage analysis simulation, the factor of safety (FS) value decrease to 1.209. The factor of safety (FS) value in the range between 1 and 1.25 classified as a less stable slope, which means the minor disturbance can disturb the slope stability. The decrease in the factor of safety (FS) value occurred due to the changes in soil pore water pressure. Pore water pressure will increase the load and shear stress of soil. If the shear resistance of soil exceeded, it will cause landslides [22].

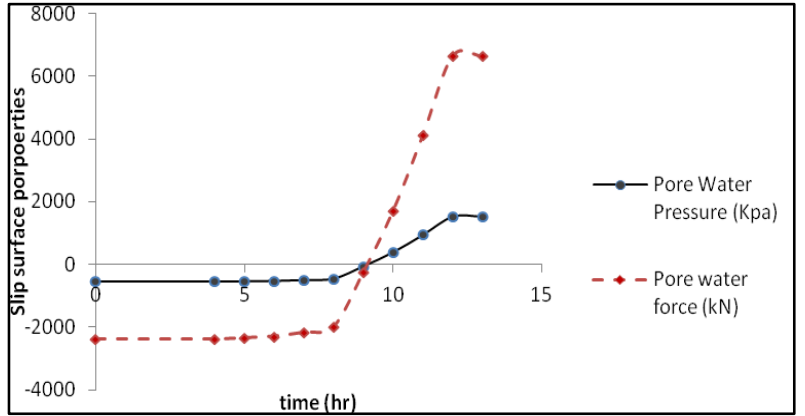

Fig. 6. The changes of slip surface properties to rainfall duration

Figure 6 shows the change in pore water pressure and pore water force to rain duration. At the beginning of the simulation, the pore water pressure and pore water forces are negative and eventually become positive as the duration of rain increases. Pore water pressure and pore water force values are negative in dry soil. This value will increase if there is soil wetting and will be zero when it is exactly as high as the groundwater level. It will be positive and higher if it moves away from the groundwater level until the soil becomes saturated. In the saturated condition, the rainwater fills the pore space that makes components of soil changes into land and water only. The value of pore water pressure will be lower than the pore water pressure when the pore water pressure value is negative. Contrarily, the pore water pressure value will be higher than the pore water pressure when the pore water pressure value is positive.

Based on Figure 5 and Figure 6., it can define that the value of pore water pressure is contrary to the factor of safety (FS) value. In conclusion, heavy rainfall can trigger the instability slope in the Imogiri Cemetery, but rainfall loads cannot cause the landslide in the Imogiri cemetery without other triggers. The result of this study is close to the real conditions in the location of landslides because there are no earthquake loads add in this simulation.

\section{Conclusions}

The result of the analysis is the factor of safety (FS) value, defined as the ratio of the shear strength to the shear stress. Without the rains, the FS value is about 2.44, which means the slope stability is stable. After heavy rainfall, the FS value decreased to 1.209 at the end of the simulation, which indicates happen the slope instability. Based on the simulation, the FS value depends on the volume of water content and hydraulic conductivity. Result of this study shows that heavy rainfall can trigger the instability slope in the Imogiri Cemetery, but rainfall loads cannot cause the landslide in the Imogiri cemetery without other triggers. In this study, no simulation was carried out with the influence of the load due to earthquake factors, even though the study location was prone to earthquakes. For further research, it can be reanalyzed by adding the effect of the load due to the earthquake. 
The author gratefully acknowledgement the assistance of Atma Galih D., Amalia Irawan, Nina Budiono and the consultant team of Imogiri project during the data collection.

\section{References}

1. I. Risdiyanto. Identifikasi Daerah Rawan Longsor, [Research]. 1-2 (2011). [in Bahasa Indonesia]. DOI: 10.13140/RG.2.1.4316.5684

2. K.B. Suryolelono, Landslides: a persepective of Eng. Geology, Speech of Inauguration of Professor Position (2002)

3. H. Rahardjo, A. Satyanaga, E.C. Leong, E3S Web of Conferences E-UNSAT, 9, 15004:1-6(2016)

4. M. F. Ahmed, X. Kang, M. S. Khan, Int. J. Econ. Environ. Geol, 7:20-25(2016)

5. X. Jing, Y. Chen, C. Pan, T. Yin, W. Wang, X. Fan, Int. J. Environ. Res. and Public Health, 16:1-11 (2019)

6. USGS. The Landslide Handbook-A Guide to Understanding Landslides, 46(2008)

7. National Disaster Management Authority, BNPB Pocket Book, 46-47(2017)

8. I. Susanti, S. B. Sipayung, N. Cholianawati, S.A. rahayu, L. Slamet, R. Sunarya, Proc. SNSAA, 148157(2012)

9. S. H. Soenarmo, I. A. Sadisun, E. Saptohartono, J. Geopalika, 3:133-141(2008)

10. S. Haryanti, K. B. Suryolelono, R. Jayadi, J. Ilmiah Semesta Teknika, 13:105-115(2010) [in Bahasa Indonesia]

11. Priyono, GEMA, 49:1602-1617(2007)

12. K. D. Priyono, Y. Priyana, Priyono, Forum Geografi. 20: 175-189 (2006)
13. M. Yuwono, Makam Raja Mataram di Imogiri Longsor (Landslide in the Graveyard Complex of Mataram Royal Kings), Available at: https://regional.kompas.com/read/2019/03/18/1424 5801/makam-raja-mataram-di-imogiri-longsor accessed on January 19, 2020 (2019)

14. M. H. Wismabrata, 6 Fakta Banjir dan Longsor di DIY, Bantul Paling Parah hingga Terjang Kompleks Makam Raja di Imogiri (6 Facts of Floods and Landslides in DIY, the Most Severe Bantul to Lunge the King's Tomb Complex in Imogiri), Avaliable at: https://regional.kompas.com/read/2019/03/18/1649 1391/6-fakta-banjir-dan-longsor-di-diy-bantulpaling-parah-hingga-terjang accessed on January 19, 2020 (2019)

15. N. Gofar, H. Rahardjo, MATEC Web of Conf. SICEST, 101, 05004 (2017)

16. H. C. Hardiyatmo, Soil Mechanics 2:465468(2018)

17. W. Wilopo, Kajian Geologi Gerakan Tanah dan Banjir di Kabupaten Bantul, Yogyakarta (Geological Study of the Landslide and Flood in Bantul Regency, Yogyakarta) (2019)

18. National Standardization Agency, SNI1727:2013, 15-60 (2013)

19. GEO-SLOPE International Ltd., Seepage Modelling with SEEP/W, 76-78 (2012)

20. M. Vernay, M. Morvan, P. Breul, E3S Web of Conferences E-UNSAT, 9, 14002 (2016)

21. X. Zhao, Y. Sun, Q. Feng, IOP Conf. Ser.: earth Environ. Sci., 170, (2018)

22. A. Muntohar, J. Ikhsan, Geo-Congress, 452-461 (2013) 